\title{
ZONE ELECTROPHORETIC STUDIES OF PLASMA PROTEINS IN RHEUMATOID ARTHRITIS AND ANKYLOSING SPONDYLITIS*
}

\author{
BY \\ T. E. HUNT and J. A. TREW \\ From the Arthritis Research and Treatment Centre and the Department of Pathology, \\ Regina General Hospital, Regina, Saskatchewan, Canada
}

(RECEIVED FOR PUBLICATION JUNE 18, 1954)

This paper is a report of our investigations into the estimation of plasma proteins by zone electrophoresis; and the relationship between the level of the plasma fibrinogen and the erythrocyte sedimentation rate in patients with rheumatoid disease. The effects of various forms of treatment is also described.

\section{Material}

The material in this study consists of 172 zone electrophoretic analyses of plasma proteins; 23 from eighteen normal subjects and 149 from 25 patients suffering from rheumatoid arthritis or ankylosing spondylitis. Sixteen replicate analyses were carried out on serum obtained from one of the normal subjects. In addition, plasma fibrinogen levels were determined, by precipitation, on 173 occasions, in the patients and in fourteen of the healthy persons. Sedimentation rates were performed concurrently in all instances.

Twenty of the patients were diagnosed as having typical peripheral rheumatoid arthritis, four of these being children under the age of 12 ; one patient had pure ankylosing spondylitis, and four were suffering from spondylitis with peripheral joint involvement. All patients were hospitalized in the Arthritis Research and Treatment Centre, Regina General Hospital, under the auspices of the Saskatchewan Division of the Canadian Arthritis and Rheumatism Society.

The ages of the normal subjects varied from 19 to 45 years, and those of patients extended from 7 to 79 years. The sex incidence of the healthy persons was evenly divided and among the patients there were thirteen men and twelve women. None of the normal group was thought to have any concurrent illness. Amongst the patients, rheumatoid disease had been present for only 6 months in two cases, but five persons had been afflicted for more than 15 years. The average duration of arthritis was $4 \frac{1}{2}$ years. Most of the patients were in the more advanced stages of the disease.

\footnotetext{
* This study was assisted by a grant-in-aid from the Canadian
} Arthritis and Rheumatism Society.
Control studies were carried out on seven patients before the institution of any specific systemic therapy, and in seven others who received no specific medication throughout their hospitalization. The remaining patients had been receiving either hormonal, gold, or $x$-ray therapy at the commencement of the study or before admission.

Interest was aroused in the relationship between the erythrocyte sedimentation rate and the plasma fibrinogen levels in rheumatoid arthritis as a result of the work in Toronto of Fletcher and others (1952). These authors reported a very definite correlation between these two estimations, particularly when the plasma globulins were within the normal range.

It was felt of interest, therefore, to investigate this relationship further and to compare the sedimentation rate with fibrinogen levels estimated by both the precipitation method and by zone electrophoresis. The initial comparisons, in this study, showed no significant correlation, although after discarding cases with high globulins some relationship did seem apparent. It was then remembered that this linear relationship is frequently upset during therapy, particularly with cortisone or ACTH, because the elevated fibrinogen level decreases before, and more rapidly than, the sedimentation rate. This was shown very clearly by Fletcher and others, who also illustrated graphically the alteration in this fibrinogen-sedimentation rate correlation. With this in mind, scattergrams were made only of analyses from plasma taken from patients with normal globulin (less than $2.5 \mathrm{~g} . / 100 \mathrm{ml}$. plasma) during control periods, and from the normal subjects.

With regard to therapy during the study, three patients received gold or cortisone alone. Four patients were given cortisone at first to which gold therapy was later added. In three cases phenylbutazone was administered alone, and in four others this drug was used in addition to maintenance cortisone treatment. (The usual doses were $37 \cdot 5-50 \mathrm{mg}$. cortisone and $200-400 \mathrm{mg}$. phenylbutazone.) One patient received $x$-ray therapy for ankylosing spondylitis. 


\section{Methods}

The erythrocyte sedimentation rates were done by the Westergren method in duplicate on patients and single determinations on normal subjects.

The plasma fibrinogens were determined by two methods: first by that described by Campbell and Hanna (1937), in which the fibrinogen was precipitated with sodium sulphite, redissolved, and estimated photometrically according to the procedure of Gornall and others (1949); secondly, by the zone electrophoresis technique described below.

Total serum protein, albumin, and total globulin estimations were carried out by the precipitation-biuret method at least once on each control and each patient.

Complete protein fractionations were carried out, using the zone electrophoretic technique, a modification of that described by Flynn and De Mayo (1951), which is essentially a combination of the methods of Durrum (1950) and of Cremer and Tiselius (1950).

Apparatus.-The electrophoretic apparatus (Fig. 1A) was modified to consist of a methacrylate plastic box, $24 \times 10^{\prime \prime}$, with two buffer compartments, $10 \times 1 \frac{1}{2}$, at either end. The outer compartments contained the carbon rod electrodes and a filter paper bridge connected the two compartments. A glass plate, $17 \times 10^{\prime \prime}$, formed the filter paper support between the two inner compartments. The paper strips were placed across the support so that the ends dipped into the inner buffer compartments. A glass plate covered the entire assembly, being pressed down carefully on the paper strips.

Technique.-The paper strips, No. 1 Whatman, $2 \frac{1}{2}{ }^{\prime \prime}$ wide, saturated with barbiturate buffer, $p \mathrm{H} 8 \cdot 6$, were stretched across the supporting plate with each end dipping into the buffer solution. Another filter paper strip was used to remove the excess solution from the area to which the plasma was to be applied. $0 \cdot 10 \mathrm{ml}$. plasma was streaked across the paper to give a line about $1 \mathrm{~cm}$. wide. The cover plate was then lowered into place, both plates having previously been coated with silicone grease to reduce absorption of the protein on the glass. The current was applied across the system at the rate of about 0.4 milli-ampères per centimetre width of̣. paper for 6 hours. Three samples were run simul taneously. A D.C. power unit, producing up to $550 \mathrm{v}$. regulated, was required. The cover glass was removedo the ends of the paper trimmed off, and the strips air dried overnight.

The staining procedure was exactly the same as thatid of Flynn and De Mayo (1951).

A densitometer, described below, was used to obtain the data from which the electrophoretic curve was plotted on graph paper. The curve of each fractionwas drawn to overlap the next fraction at the minima $\vec{\omega}$ between the two. The area for each curve was obtained? by the method of counting the squares. The percentage of each fraction was obtained from its area in relation to the total area.

The densitometer, or scanning device, was con $\omega$ structed according to the description given by Griffiths (1952). It was built on a box, $22 \times 12 \times 4^{\prime \prime}$, with two removable glass plates, $18 \times 3^{\prime \prime}$, covering a hole in the top $2 \frac{1}{2}$ " wide and extending the full length of the top (Fig. 1B, opposite). Above the glass plates was mounted a 100-w. $C$ white-light source, focussed through a slit $1 \frac{1}{2} \times \frac{1}{10}$ " in the base of the lamp-housing, the axis of the slit being at right angles to the length of the glass plates. Directlyo below the light source and connected to it with a bracket, a rectangular photo-electric cell was installed. whole assembly moved above and below the glass plasess by means of a screw moving $\frac{1}{10}$ " between each readi The photo-electric cell was mounted in a black plașico box and the light source was protected by a sheet meta housing. The photo-electric cell was connected to क logarithmic type ohmmeter and the readings of this were recorded as relative density. When a pattern was to be read, the strip was placed between the glass plates and the density scale set at zero at a point on the strip?

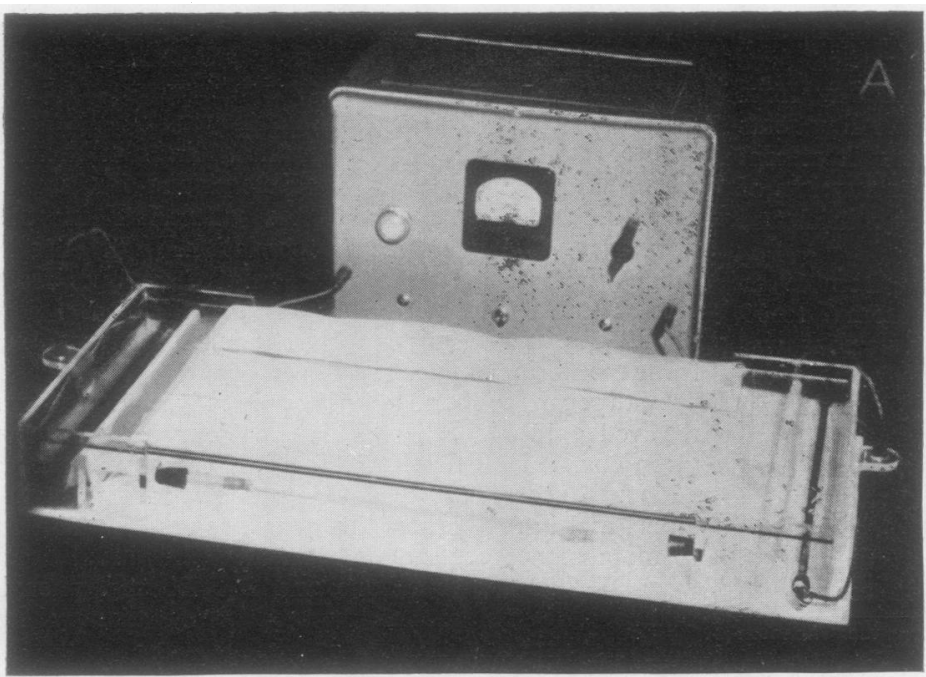

Fig. 1A.-Zone electrophoretic apparatus, showing plastic container with paper strips in position and power unit. 
Fig. 1B.-Densitometer or scanning unit.

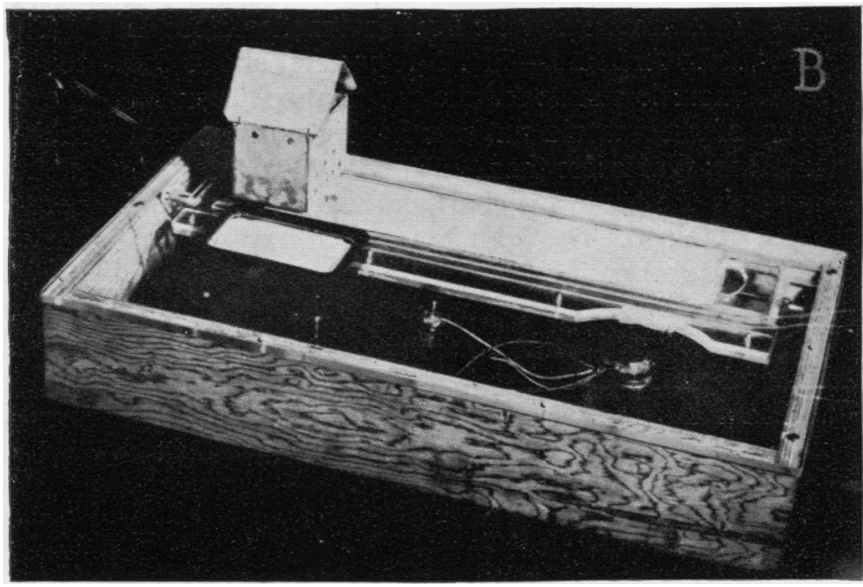

from which the dye was completely eluted. The readings then represented the relative optical density at $10^{\prime \prime}$ intervals along the strip.

The necessary technical procedure to do six analyses required about 3 hours. The apparatus required no attention during the electrophoretic separation except the occasional adjustment of the current. This represents considerable reduction in time required for complete fractionation by salt-precipitation procedures.

A large number of the initial samples were quickfrozen for storage. This was found unsatisfactory since the fibrinogen tended to form a precipitate which did not redissolve on warming to room temperature. That difficulty was later avoided by the use of fresh samples only. None of the original material was included, therefore, in this report.

\section{Observations}

(a) Evaluation of Precision of Zone-Electrophoresis Technique.-Two samples of blood were

TABLE I

REPRODUCIBILITY OF ANALYSES ON ONE SAMPLE OF SERUM

(Per cent. of Total Protein)

\begin{tabular}{|c|c|c|c|c|c|}
\hline Analyses & . & Albumin & $\begin{array}{l}\text { Alpha- } \\
\text { Globulin }\end{array}$ & $\begin{array}{c}\text { Beta- } \\
\text { Globulin }\end{array}$ & $\begin{array}{l}\text { Gamma- } \\
\text { Globulin }\end{array}$ \\
\hline & & $\begin{array}{l}81 \cdot 5 \\
86 \cdot 0 \\
88 \cdot 5 \\
77 \cdot 0 \\
82 \cdot 5 \\
84 \cdot 0 \\
80 \cdot 5 \\
81 \cdot 0 \\
80 \cdot 0 \\
85 \cdot 0 \\
84 \cdot 2 \\
89 \cdot 4 \\
81 \cdot 9 \\
71 \cdot 2 \\
78 \cdot 5 \\
82 \cdot 2\end{array}$ & $\begin{array}{l}5 \cdot 3 \\
3 \cdot 4 \\
3 \cdot 9 \\
6 \cdot 4 \\
3 \cdot 5 \\
6 \cdot 1 \\
4 \cdot 4 \\
5 \cdot 6 \\
5 \cdot 3 \\
4 \cdot 1 \\
3 \cdot 4 \\
2 \cdot 5 \\
6 \cdot 0 \\
8 \cdot 0 \\
4 \cdot 8 \\
5 \cdot 7\end{array}$ & $\begin{array}{l}8 \cdot 8 \\
5 \cdot 1 \\
3 \cdot 5 \\
6 \cdot 2 \\
6 \cdot 4 \\
4 \cdot 3 \\
5 \cdot 1 \\
6 \cdot 4 \\
7 \cdot 8 \\
4 \cdot 2 \\
5 \cdot 7 \\
3 \cdot 6 \\
5 \cdot 7 \\
9 \cdot 5 \\
7 \cdot 0 \\
6 \cdot 0\end{array}$ & $\begin{array}{r}4 \cdot 4 \\
5.5 \\
3.5 \\
10.5 \\
7.5 \\
5.7 \\
9.8 \\
6.7 \\
6.9 \\
6 \cdot 8 \\
6.7 \\
4.6 \\
6.6 \\
11.2 \\
9.9 \\
6.0\end{array}$ \\
\hline Mean .. & $\cdots$ & $82 \cdot 1$ & $4 \cdot 9$ & $5 \cdot 3$ & $7 \cdot 0$ \\
\hline $\begin{array}{l}\text { Standard } \\
\text { Deviation }\end{array}$ & . & $4 \cdot 40$ & $1 \cdot 43$ & $1 \cdot 86$ & $2 \cdot 26$ \\
\hline
\end{tabular}

obtained from one individual on consecutive days, and the serum separated and mixed. Sixteen replicate analyses were done on the serum on successive working days, the serum being stored in the refrigerator between analyses. Although the main part of the work in this report concerns plasma, serum was used here because it could be more satisfactorily stored. The results of these replicate analyses, including the mean values and the standard deviation, are given in Table I.

(b) Zone Electrophoretic Protein Fractionations in Normal Controls. - The results of the plasma protein estimations in the normal series are shown in Fig. 2 (overleaf).

Part $\mathrm{A}$ is the incidence chart and shows the range of values obtained for the normal group, Part B shows the pattern obtained for an average normal person, and Part $\mathrm{C}$ the electrophoretic curve derived from the density readings along this strip. The fractions and the percentages of each are indicated in the figure. Table II shows the ranges actually observed together with the relevant statistical calculations.

TABLE II

ZONE ELECTROPHORESIS ON SERUM OF NORMAL SUBJECTS

\begin{tabular}{|c|c|c|c|c|}
\hline Estimation & $\begin{array}{c}\text { Actual } \\
\text { Range } \\
\text { Observed } \\
\text { (per cent. } \\
\text { of total } \\
\text { protein) }\end{array}$ & $\begin{array}{c}\text { Mean } \\
\text { Value } \\
\text { (per cent. } \\
\text { of total } \\
\text { protein) }\end{array}$ & $\begin{array}{l}\text { Sigma } \\
\text { (per cent. } \\
\text { of total } \\
\text { protein) }\end{array}$ & $\begin{array}{l}\text { Per cent. } \\
\text { of Total } \\
\text { Protein } \\
\text { (statistical } \\
\text { range based } \\
\text { on mean } \\
\pm 2 \sigma \text { ) }\end{array}$ \\
\hline 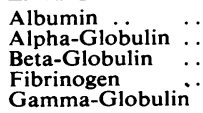 & $\begin{array}{r}61 \cdot 6-78 \cdot 4 \\
2 \cdot 4-7 \cdot 4 \\
5 \cdot 1-11 \cdot 5 \\
7 \cdot 0-15 \cdot 3 \\
5 \cdot 1-10 \cdot 0\end{array}$ & $\begin{array}{r}68 \cdot 6 \\
5 \cdot 0 \\
7 \cdot 5 \\
10 \cdot 5 \\
9 \cdot 4\end{array}$ & $\begin{array}{l}4 \cdot 8 \\
2 \cdot 4 \\
1 \cdot 8 \\
2 \cdot 0 \\
2 \cdot 5\end{array}$ & $\begin{array}{r}59 \cdot 0-78 \cdot 2 \\
2 \cdot 6-7 \cdot 4 \\
3 \cdot 9-11 \cdot 1 \\
6 \cdot 5-14 \cdot 5 \\
4 \cdot 4-14 \cdot 4\end{array}$ \\
\hline
\end{tabular}


(c) Zone Electrophoretic Protein Fractionations in Rheumatoid Arthritis.-Fig. 3 (opposite) shows the electrophoretic results for the pre-treatment control group of rheumatoid patients having normal total globulins; that is less than $2 \cdot 5 \mathrm{~g}$. per $100 \mathrm{ml}$. plasma. Part $\mathrm{A}$ is the incidence chart showing the range of values obtained. The average for each fraction was as follows: albumin 53.0 per cent.; alpha-globulin 8.5 per cent.; beta-globulin 8.5 per cent.; gammaglobulin 17.7 per cent.; fibrinogen 15.0 per cent. of the total protein. Parts $B$ and $C$ show the actual pattern and curve for one patient in this group.
The electrophoretic results for the total rheumatoid group are shown in Fig. 4 (overleaf). Part $A$ is the incidence chart and shows the ranges for the individual fractions. The average for each was: albumin 54.0 per cent.; alpha-globulin $7 \cdot 0$ per cent.; beta-globulin 7.0 per cent.; gamma-globulin 16.0 per cent.; fibrinogen 16.0 per cent. Parts B and C show the electrophoretic pattern and curve respectively for a typical separation in this group. Parts $D$ and $E$ show the pattern and curve for one case with a high fibrinogen value, 26.7 per cent., and a very high gamma-globulin, 33.4 per cent.
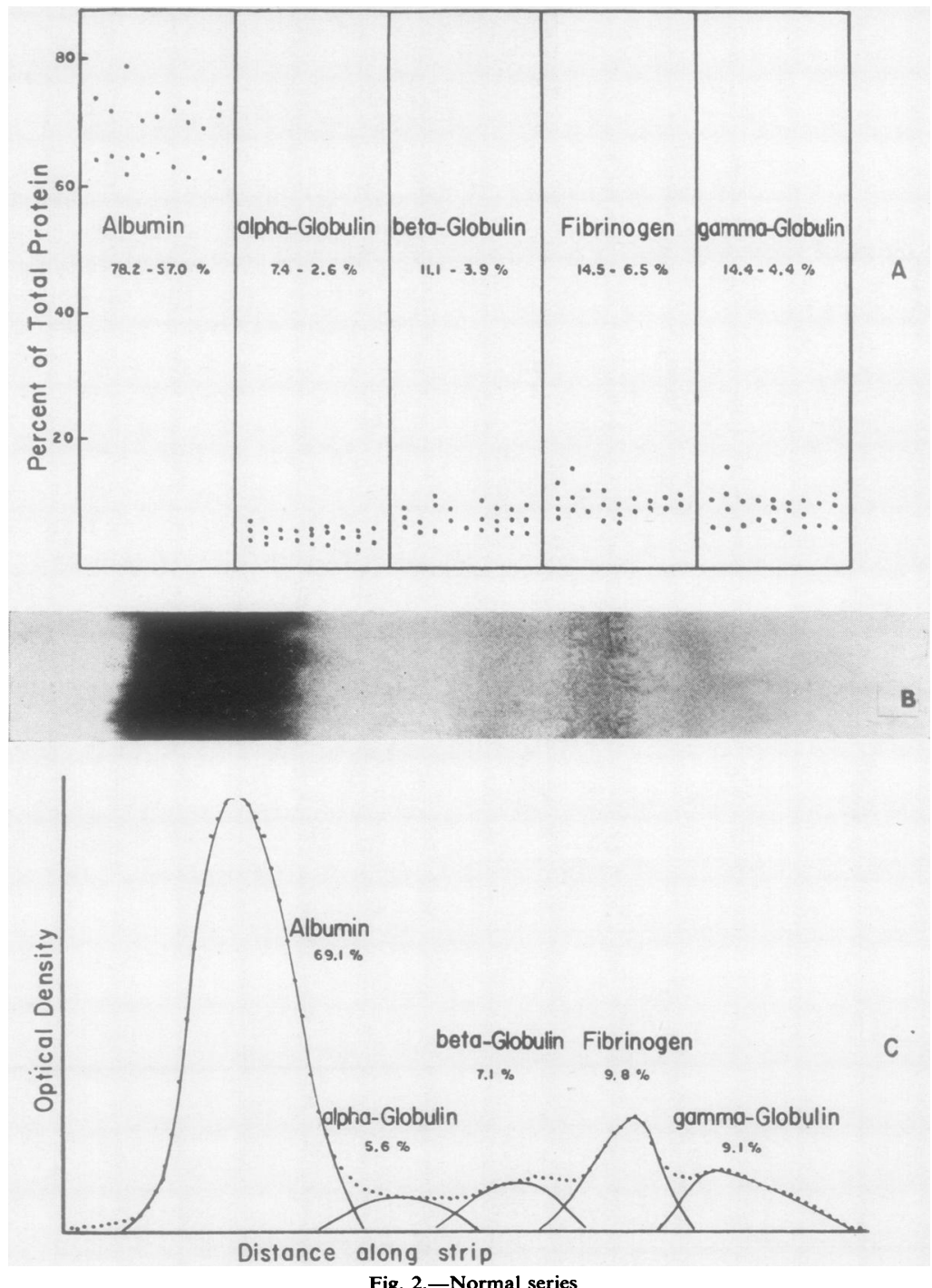

Fig. 2.-Normal series

A. Incidence of values obtained for protein fractions by zone electrophoresis.

B. Zone pattern for a typical analysis in this group.

C. Electrophoretic curve derived from $B$. 

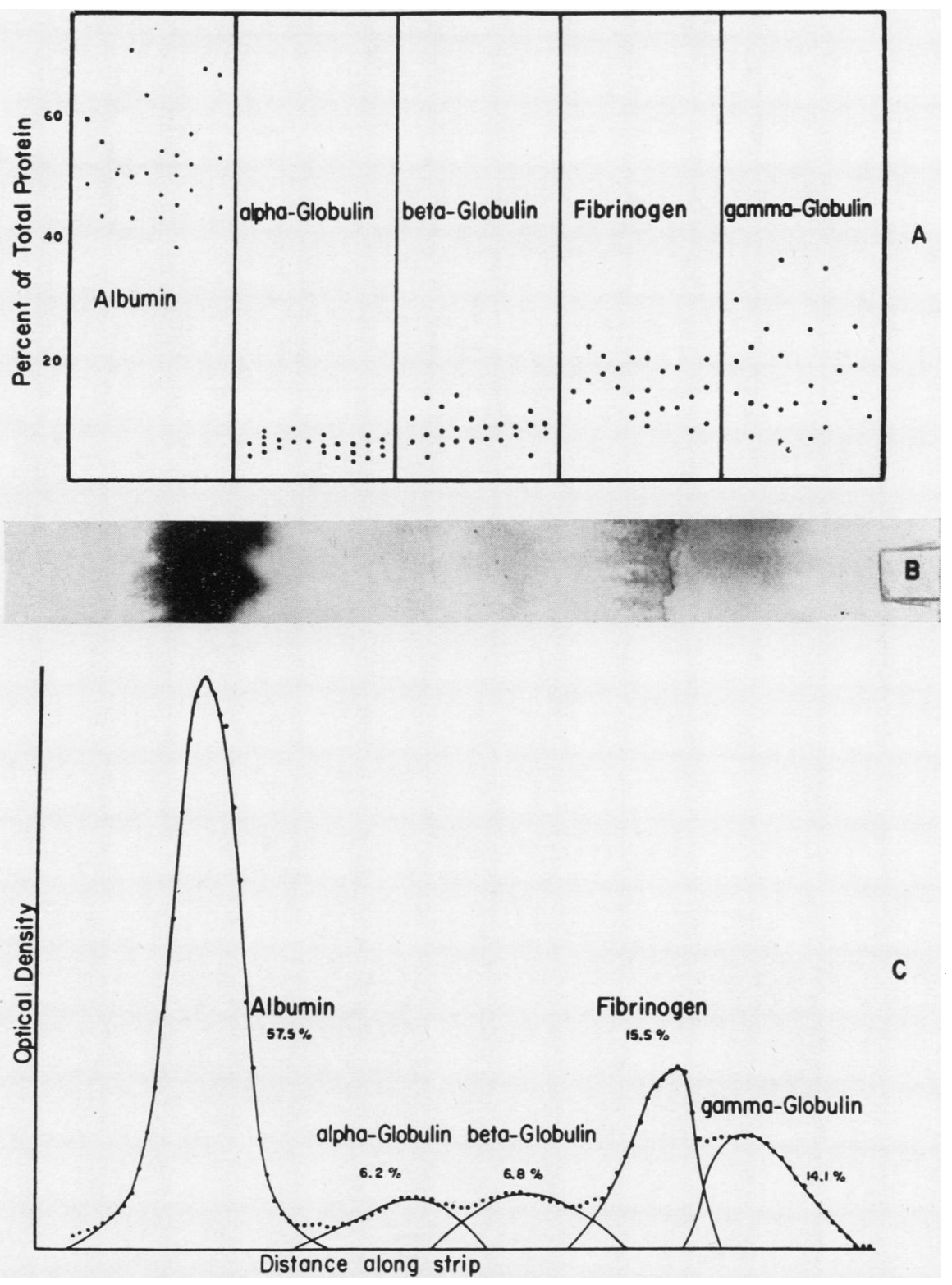

Fig. 3.-Pre-treatment control group.

A. Incidence of values obtained for protein fractions by zone electrophoresis.

B. A typical pattern for this group.

C. Electrophoretic curve derived from B.

(d) Correlation of Erythrocyte Sedimentation Rates with Fibrinogen estimated by the Two Methods. -

Figs 5 and 6 (overleaf) show scattergrams of sedimentation rates and fibrinogen levels from patients with normal total globulin levels and from normal subjects. A definite linear relationship is apparent with either method of fibrinogen estimation. The statistical data is shown with the Figures. At this point it might be noted that, in the zoneelectrophoretic analyses, relative fibrinogen levels only are being considered. In this study it was not attempted to obtain actual fibrinogen concentration by electrophoresis. Such a study is at present in progress and will be reported at a later date. Until such time as this is accomplished, these initial results confirm the work of the Toronto group. In addi- 

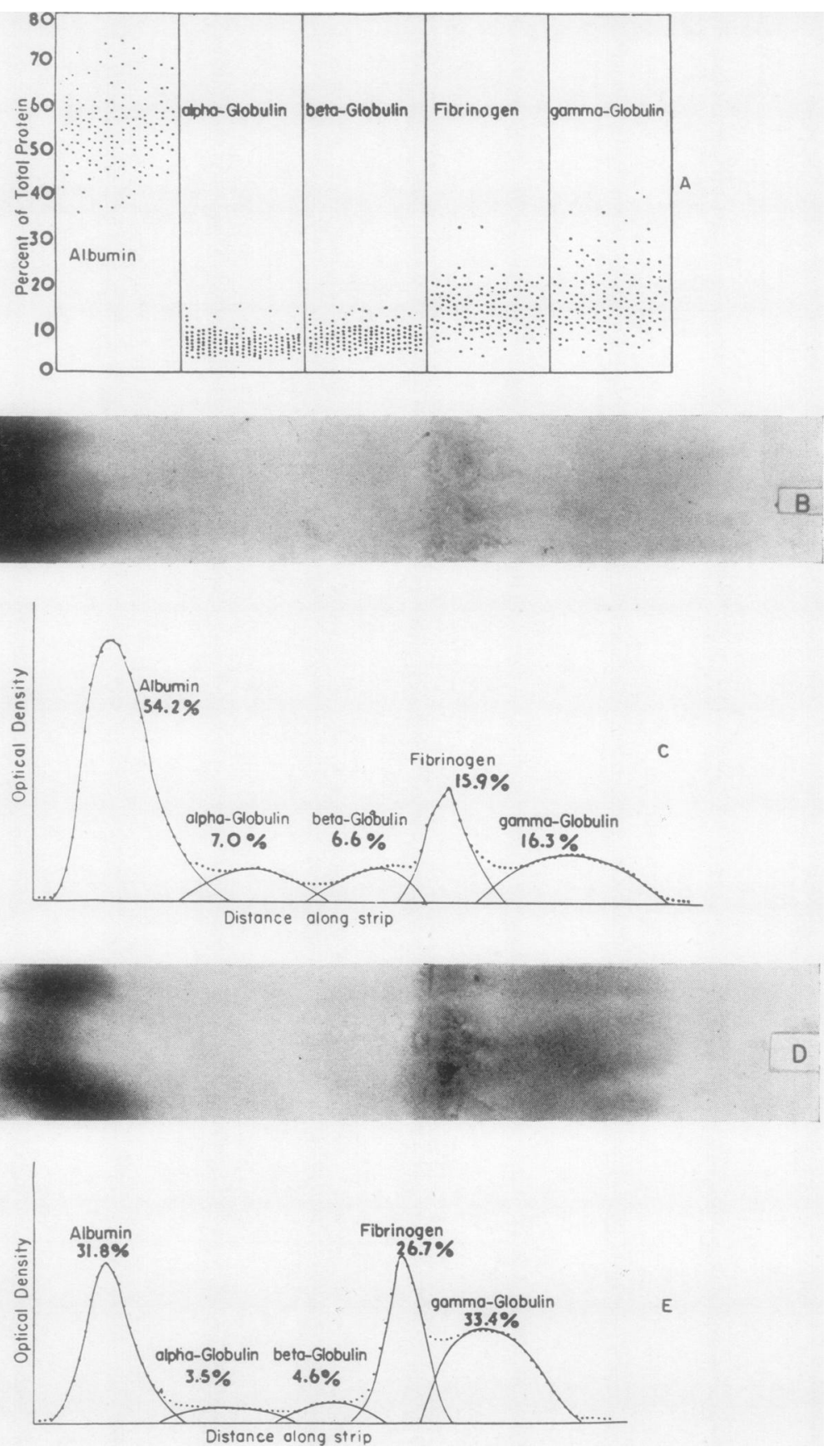

Fig. 4.-Total rheumatoid arthritic group and one extreme case.

A. Incidence chart for total rheumatoid group of 149 electrophoretic determinations.

B. Pattern of a typical separation in this group.

C. Electrophoretic curve derived from B. (Fractions and percentage of each are indicated.)

D. Pattern of an extreme case, showing very low albumin and high fibrinogen and gamma-globulin.

E. Electrophoretic curve derived from D. 


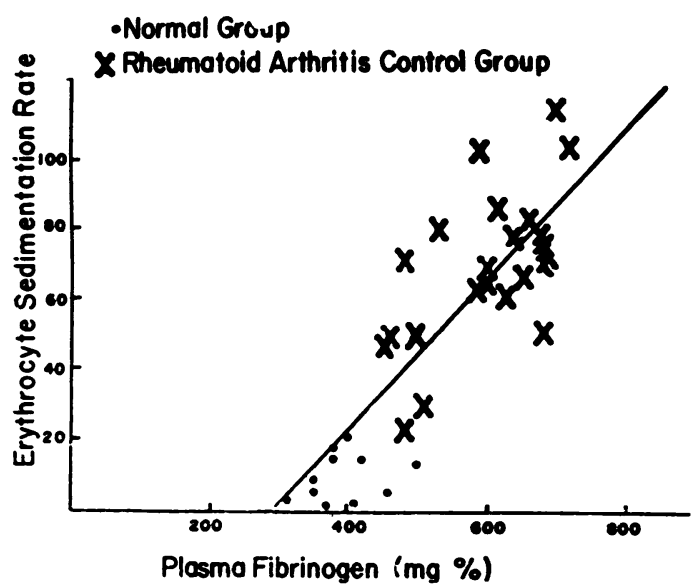

Fig. 5.-Correlation of erythrocyte sedimentation rates with fibrinogen.

Erythrocyte sedimentation rate $v$. fibrinogen by 12.5 per cent. sodium sulphite precipitation.

Coefficient of linear correlation, $r=0.863$

Regression equation $E=0.215 \quad F_{S}-65.4$

where $E=$ sedimentation rate and

$F_{\mathrm{s}}=$ fibrinogen $(\mathrm{mg} .1100 \mathrm{ml}$. plasma)

$t=5.07$

$P<0.001$.

tion, as will be discussed later, the zone-electrophoretic analysis would appear to be the less accurate of the two methods, although probably sufficiently reproducible to be of value in a general hospital laboratory, or smaller rheumatism centre.

(e) Results of Therapy.-As it has long been known that the fibrinogen level of the plasma and the erythrocyte sedimentation rate are indices of the activity of rheumatoid disease, these estimations were used to follow the course of patients during hospitalization with or without specific anti-rheumatic therapies.

(i) No Specific Therapy.-As was expected, only minor fluctuations in the fibrinogen levels and in the sedimentation rates occurred upon following the courses of the patients receiving no specific therapy and in the control group prior to the institution of therapy. Throughout the course of each patient study, the minor alterations in sedimentation rates closely paralleled slight changes in the fibrinogen levels.

(ii) Cortisone and Combination Therapy.Those patients receiving cortisone showed the expected decrease in sedimentation rates and concurrent reductions in plasma fibrinogen levels during therapy with higher doses of the hormone as shown in Fig. 7. On reducing the dosage of the drug to maintenance amounts, the values of these indices tended to level off or to rise again even though the clinical features remained suppressed.

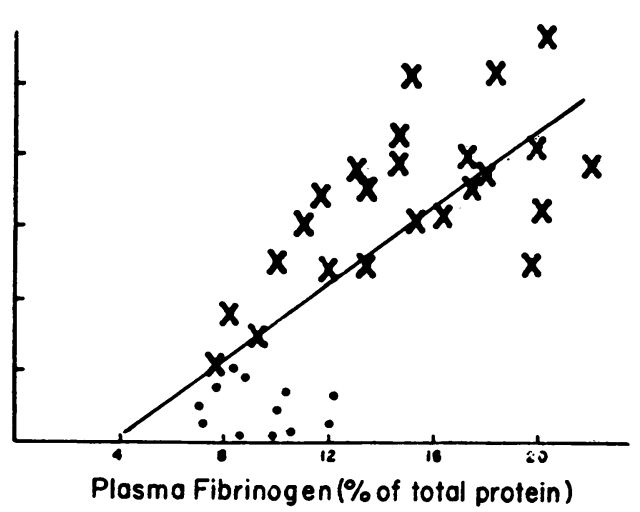

Fig. 6.-Correlation of erythrocyte sedimentation rates with fibrinogen.

Erythrocyte sedimentation rate $v$. relative fibrinogen level by zone electrophoresis.

Coefficient of linear expansion, $r=0.750$

Regression equation $E=5 \cdot 64 F_{e}-25 \cdot 1$

where $E=$ sedimentation rate

$F_{\mathrm{e}}=$ fibrinogen (per cent. of total plasma

$t=4 \cdot 50$

$P<0.001$.

The addition of gold therapy to maintenance dosages of cortisone did not significantly alter the clinical or laboratory courses of the four patients for which this treatment was prescribed.

Small doses of phenylbutazone added to maintenance dosages of cortisone produced marked clinical improvement in three cases in this group but the fourth obtained no benefit. In the former there was a marked relief of pain and stiffness; mobility of joints increased; and a slight decrease in joint swelling occurred. However, in all cases the addition of these doses of phenylbutazone produced no alteration in the elevated sedimentation rates or fibrinogen levels.

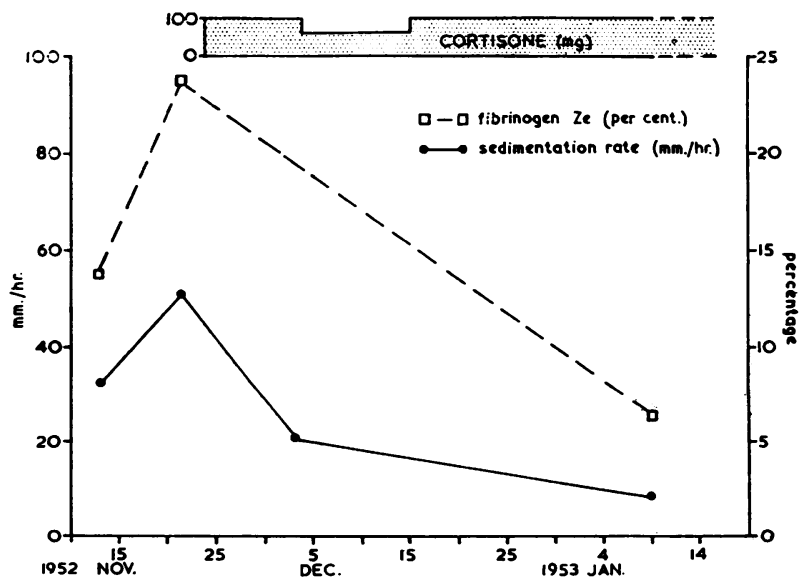

Fig. 7.-Response to cortisone in a man aged 79 of sedimentation rate and fibrinogen level (per cent. of total protein) by zone electrophoresis. 


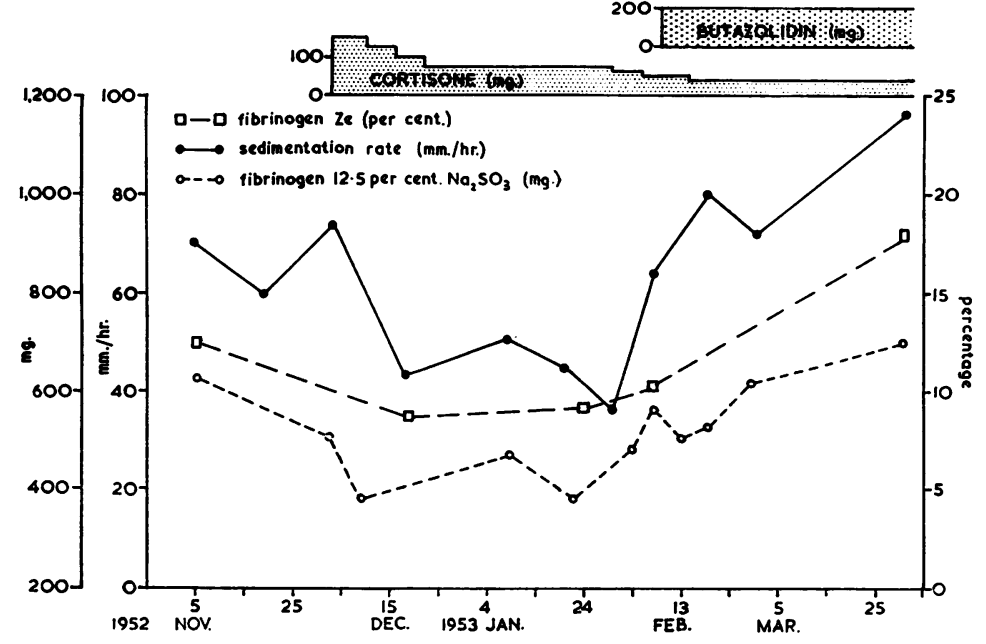

Fig. 8.- Response to cortisone with later addition of Butazolidin in a woman aged 65 of sedimentation rate, fibrinogen level by sodium sulphite precipitation, and fibrinogen level (per cent. of total protein) by zone electrophoresis.

Fig. 8 illustrates a typical case in this group. It shows a fall in all indices with satisfactory doses of cortisone and "holding" on maintenance doses of $75 \mathrm{mg}$. per day. Reducing the dosage of the hormone to $50 \mathrm{mg}$. daily or less resulted in a marked rebound which was unaffected by the doses of phenylbutazone used ( $200 \mathrm{mg}$. daily). This combination, however, did produce a satisfactory clinical response throughout the rest of this patient's hospital stay.

(iii) Phenylbutazone.-This drug was administered, alone, to three patients, in doses of $800 \mathrm{mg}$. per day, with gradual reduction to maintenance levels of $400 \mathrm{mg}$. daily. All received satisfactory relief of pain and increased mobility of joints. In two, joint swelling decreased. A fall in the laboratory indices, however, was seen in only one instance which is shown in Fig. 9. Again a very good correlation between the sedimentation rate and fibrinogen level is evident.

(iv) Gold Therapy.-Three patients received gold therapy in addition to the usual basic programme of balanced rest and activity, physiotherapy and remedial exercises. Moderate to marked clinical improvement occurred in all.

In one case no significant alterations appeared in either the sedimentation rates or the fibrinogen levels during the period of study. Determinations for this study were carried out on the second patient only during maintenance treatment. These revealed sedimentation rates consistently within the normal range (elevated prior to treatment) while the fibrinogen fractions of the plasma remained elevated. This seeming paradox in cases receiving gold has been well recognized.

The third patient's laboratory course was extremely erratic with many exacerbations and remissions throughout. Here, as in the first case, good correlation existed between the various indices, but no laboratory evidence of a beneficial effect from treatment was apparent.
Discussion

The zone electrophoretic technique does appear to offer possi- $\bar{c}$. bilities as a screening method of studying protein fractionations, $\stackrel{\stackrel{\rho}{\rightarrow}}{D}$ and the results of this study indi-? cate that it can provide a useful $\frac{\bar{F}}{\bar{N}}$ means of following the course of $\frac{\rho}{\bar{\sigma}}$ patients with rheumatoid disease. $\stackrel{\complement}{\complement}$ However, the method presents a के number of undesirable features $\vec{\circ}$ which would seem to obviate its use in more detailed, exacting $\vec{\omega}$ investigations.

Among the difficulties encoun- $\frac{0}{2}$ tered in the zone electrophoretic $\vec{\omega}$ technique was one termed "edge $\omega$ effects", by which evaporation i from the edge of the glass plates tended to distort the protein pat- $\frac{}{5}$ tern so that the zones were not $\overrightarrow{C D}$ at right angles to the axis of the paper. The effect $\mathbb{D}$ was not a consistent one and was not readily attri- $\frac{\mathrm{O}}{\mathbb{D}}$ buted to changes in room temperature since the $\frac{D}{3}$ separation was done in a room with all openings $\stackrel{\mathbb{\Phi}}{-}$ closed. Other workers have sealed these edges by $\overrightarrow{0}$ various methods; by smearing the edge with grease of or by immersing the whole assembly in water inm. miscible solvents. Our separations were done witt a blank strip of buffer soaked paper, $1^{\text {" }}$ wide at each edge. In effect this displaced the edge effect away from the strip carrying the sample.

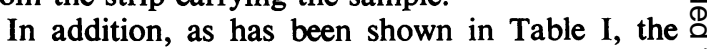
reproducibility of results utilizing the technique $\overrightarrow{\overrightarrow{0}}$

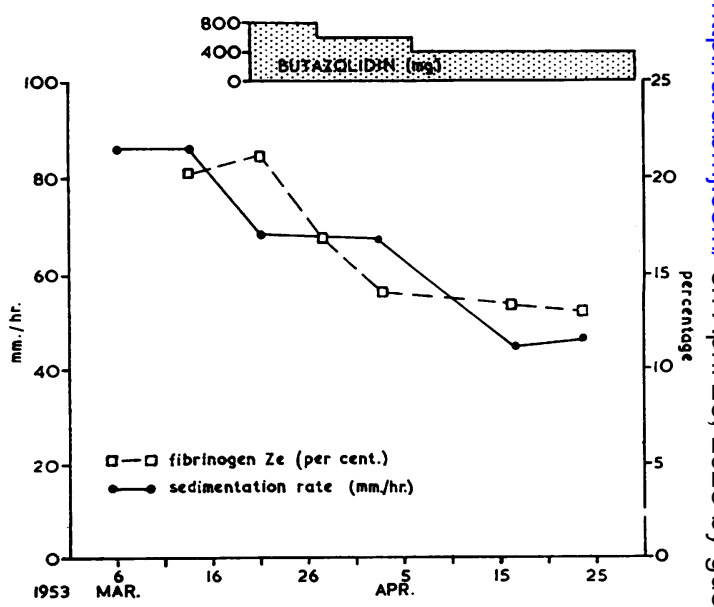

Fig. 9.-Response to Butazolidin in a woman aged 53 of sedimentation rate and fibrinogen level (per cent. of total protein) by zone electrophoresis. 
described leaves something to be desired. Also the percentage levels for fibrinogen (Table II) for normal controls are found to be consistently high as compared with other methods.

The problem here would appear to involve mainly difficulties in deriving the points of separation between the various fractions, particularly the fibrinogen and gamma-globulin. This became evident both during the scanning of the coloured strips, and during the plotting and calculation procedures. In an attempt to obtain better separation, other workers, such as Kay (1954), have employed smaller currents of longer duration and have utilized different dyes. These modifications would appear to be very advantageous for analyses of serum, but, in the case of plasma, difficulties still exist in the separation of the two fractions noted previously. This is because of the slow and almost equal movements of these two components during electrophoresis, which almost always result in some degree of overlapping of the fibrinogen and gammaglobulin fractions (Figs 2, 3, and 4).

Again, it has been observed that the fibrinogen, particularly when increased in amount, tends to "gel" resulting in irregular, streaky distribution on the filter paper of this component and the gammaglobulin as well (Fig. 4D). This phenomenon was greatly increased when stored specimens were analysed, as was noted earlier, and it was minimized by the use of absolutely fresh plasma samples.

For these reasons, and until they can be overcome, this technique as applied to plasma protein fractionations would seem to be inferior to the older methods of study.

On the other hand, the apparatus and procedures are relatively simple, and the saving of technical time, as compared with other methods, is considerable. These factors, together with its demonstrated clinical applicability, indicate that the zone electrophoresis technique of serum or plasma fractionations can be utilized in the laboratories of smaller general hospitals or rheumatism centres.

\section{Summary}

(1) A relatively simple method of estimating the five major components of the plasma protein is described, together with the apparatus used.

(2) By this method, in rheumatoid arthritis and ankylosing spondylitis, a moderate to marked rise is found in the relative fibrinogen and gammaglobulin levels, while the plasma albumin tends to be correspondingly reduced. No significant alterations in alpha- and beta-globulins are apparent.

(3) The results of the study relating sedimentation rate estimations to plasma fibrinogen levels in rheumatoid disease again demonstrate, as shown by Fletcher and others (1952), the linear correlation between these factors. This correlation is not as impressive with fibrinogen percentage levels obtained by zone electrophoresis as with the estimations obtained by precipitation with sodium sulphite. However, the former is statistically significant and indicates that the technique used is suitable for general clinical use, particularly in patients with rheumatoid disease.

(4) The progress of various patients has been followed during various forms of therapy, and typical graphs are presented utilizing the sedimentation rate and plasma fibrinogen levels as indices of the activity of rheumatoid disease.

(5) Some of the problems and undesirable features of the technique are discussed.

The authors wish to acknowledge the technical assistance of Miss Helen Keay, the photographic work of Mr. Harry Wood, and the constructive criticism of Dr. J. D. Stephen, Director of Laboratories, Regina General Hospital, as well as that of Drs F. T. G. Prunty and D. E. M. Kay of St. Thomas's Hospital, London, England. The apparatus was constructed with the assistance of various members of the hospital staff. We are indebted also to the Pharmaceutical Division, Geigy Co. Ltd., for the supply of phenylbutazone (Butazolidin) used in this study.

\section{REFERENCES}

Campbell, W. R., and Hanna, M. I. (1937). J. biol. Chem., 119, 15.

Cremer, H. D., and Tiselius, E. (1950). Biochem. Z., 320, 273.

Fletcher, A. A., Dauphinee, J. A., and Ógryzlo, M. A. (1952). J. clin. Invest., 31, 561.

Flynn, F. V., and De Mayo, P. (1951). Lancet, 2, 235

Gornall, A. G., Bardawill, C. J., and David, M. M. (1949). J. biol. Chem., 177, 751.

Griffiths, L. L. (1952). J. clin. Path., 5, 294.
Kay, H. E. M. (1954). Personal communication.

Etude des protéines sanguines par zones d'électrophorèse dans l'arthrite rhumatismale et dans la spondylarthrite ankylosante

\section{RÉSUMÉ}

(1) On décrit une méthode relativement simple, ainsi que l'appareil, pour déterminer les cinq composants principaux des protéines du plasma.

(2) Par cette méthode on trouve que dans l'arthrite rhumatismale et dans la spondylarthrite ankylosante il y a une augmentation modérée ou prononcée des taux relatifs du fibrinogène et de la gamma-globuline tandis que le taux de l'albumine du plasma tend à diminuer en proportion. On n'observe pas d'altérations significatives de la alpha- ni de la beta-globuline.

(3) La corrélation de la vitesse de la sédimentation globulaire et du taux du fibrinogène sanguin dans la maladie rhumatismale confirme les résultats de Fletcher et coll. (1952) montrant l'existence d'un rapport direct entre ces deux facteurs. Ce rapport n'est pas aussi impressionnant avec les chiffres du fibrinogène obtenus par la méthode électrophorétique qu'avec ceux qu'on obtient par la précipitation au sulfate de soude, mais il 
demeure toujours significatif du point de vue statistique. Le procédé décrit se prête donc à l'application clinique générale, surtout chez les rhumatisants.

(4) On a surveillé des malades au décours de différentes formes de traitement et on présente ici des courbes typiques, construites à l'aide des chiffres de la vitesse de la sédimentation globulaire et du fibrinogène sanguin comme indices d'activité de la maladie rhumatismale.

(5) On discute quelques problèmes et traits indésirables du procédé.

Estudio de las proteinas sanguíneas por zonas de electroforesis en la artritis reumatoide $y$ en la espondilartritis anquilosante Sumario

(1) Se describe un método relativamente simple, con el aparato empleado, para determinar los cinco componentes principales de las proteinas del plasma.

(2) Con este método se ve que en la artritis reumatoide y en la espondilartritis anquilosante hay aumentación moderada o pronunciada de las cifras relativas del fibrinógeno y de la gama-globulina mientras que la cifra de la albumina del plasma tiende a bajar en proporción. No se observan alteraciones significativas en la alfa- $\mathrm{n}$ en la beta-globulina.

(3) La correlación de la velocidad de la sedimentación $\Rightarrow$ eritrocitaria con la cifra del fibrinógeno sanguíneo en la enfermedad reumatoide confirma los resultados de $\tau$ Fletcher y otros (1952) que hay relación directa entre estos factores. Esta relación no es tan impresionante con las cifras de fibrinógeno obtenidas por el método electroforético que con las que se obtiene por la precipitación con el sulfato de sodio, pero queda significativa estadisticamente. El método descrito conviene pués para el empleo general clìnico en particular en los reumáticos.

(4) Enfermos sometidos a varias formas de tratamiento fueron seguidos, presentándose aquí las curvas tìpicas, construidas con la ayuda de la velocidad de la sedimentación eritrocitaria y de las cifras del fibrinógeno sanguíneo como índices de actividad de la enfermedad reumática.

(5) Se discute algunos problemas y rasgos indeseables del procedimiento. 